\title{
The stress of starvation: glucocorticoid restraint of beta cell development
}

\author{
L. C. Matthews • N. A. Hanley
}

Received: 27 September 2010 / Accepted: 6 October 2010 /Published online: 12 November 2010

(C) The Author(s) 2010. This article is published with open access at Springerlink.com

\begin{abstract}
Developmental insults during gestation, such as under-nutrition, are known to restrict the number of beta cells that form in the fetal pancreas and are maintained in adulthood, leading to increased risk of type 2 diabetes. There are now substantial data indicating that glucocorticoids mediate this effect of under-nutrition on beta cell mass and that even at physiological levels they restrain fetal beta cell development in utero. There are emerging clues that this occurs downstream of endocrine commitment by neurogenin 3 but prior to terminal beta cell differentiation. Deciphering the precise mechanism will be important as it might unveil new pathways by which to manipulate beta cell mass that could be exploited as novel therapies for patients with diabetes.
\end{abstract}

Keywords Beta cell · Corticosterone · Cortisol . Development - Glucocorticoid - Glucocorticoid receptor . Human · Insulin · Mouse · Neurogenin 3 - Pancreas · Under-nutrition

$\begin{array}{ll}\text { Abbreviations } \\ \text { E } & \text { Embryonic day } \\ \text { GC } & \text { Glucocorticoid } \\ \text { GR } & \text { Glucocorticoid receptor } \\ \text { NGN3 } & \text { Neurogenin 3 }\end{array}$

The last 20 years have seen marked interest in the hypothesis that environmental insults to the fetus can programme future cardiovascular and metabolic disorders

L. C. Matthews · N. A. Hanley $(\bowtie)$

Endocrinology and Diabetes Group, School of Biomedicine, Manchester Academic Health Sciences Centre, AV Hill Building, University of Manchester,

Manchester M13 9PT, UK

e-mail: neil.hanley@manchester.ac.uk in the offspring $[1,2]$. The 'fetal origins of adult disease' hypothesis was borne of epidemiological data associating gestational under-nutrition and low birthweight with future conditions, including type 2 diabetes. As adult euglycaemia is dependent on gaining an adequate number of insulinsecreting beta cells ('beta cell mass') as well as their subsequent maintenance, mechanistic studies have since queried how such insults might compromise beta cell development within the fetal pancreas [3].

Major understanding of beta cell specification has arisen from studying signalling pathways and nuclear transcription factors, largely in rodents, that regulate the sequential commitment of multipotent progenitors down different pancreatic lineages to terminal differentiation $[4,5]$. Variation in the balance of activity of these pathways and transcription factors within defined developmental window periods alters beta cell specification relative to other pancreatic cell types. However, superimposed on this specification 'blueprint', it is also possible to conceptualise a more subtle rheostatic control from nutrients or hormones to amplify or restrain the numbers of cells appropriately differentiating to a particular fate.

In this issue of Diabetologia, further evidence is provided from Bréant, Blondeau and colleagues for the important role of glucocorticoids (GCs) as critical hormones mediating the effect of under-nutrition on reducing beta cell mass [6]. Work by the same authors and others has previously linked maternal under-nutrition in rats with raised fetal levels of corticosterone (the main GC in rodents, comparable with cortisol in human) to an estimated halving of beta cells in the pancreas [7, 8]. Maternal adrenalectomy and baseline corticosterone replacement almost entirely abrogated this effect, implying the causal link with adrenocortical hormones [7]. Here, in corroboration, inactivating the glucocorticoid receptor (GR) in the 
developing mouse pancreas blocked the reduction in beta cell mass caused by under-nutrition [6]. Indeed during normal gestation, loss of GR led to a significant increase in beta cells $[6,8]$. The combined data demonstrate several key points. There is a central role for GC-GR signalling in restraining beta cell mass, and this occurs physiologically not just pathologically. Whereas restored or increased beta cell mass came from causing GR inactivation by $P d x I$ expression (an early event in pancreas development), that controlled by insulin expression (a late, beta cell specific event) had no effect. The regulatory sequences from both genes are widely used in mice to induce Cre recombinase production and are well validated [9, 10]. Although, theoretically, GR inactivation at duodenal sites of $P d x l$ expression might be responsible, the more likely interpretation is that GC-GR action is influential after the specification of $P d x l$-positive pancreatic progenitor cells but prior to terminal beta cell differentiation.

In addition to reducing beta cell development, GCs increased gene expression associated with exocrine development. Transcripts of the pro-exocrine transcription factor, Ptfla, amylase and carboxypeptidase A were all approximately doubled while those for the endocrine commitment transcription factor, Neurogenin 3 (Ngn3), and later markers of beta cell differentiation were slightly reduced [6]. Similarly, dexamethasone, a potent synthetic GC, increased exocrine tissue in rat explants in vitro [8]. This suggests that gestational under-nutrition via GC-GR signalling might switch multipotent pancreatic progenitors to an exocrine fate at the expense of endocrine cells. Dexamethasone can cause transdifferentiation between cell types [11]. Inducing endocrine-exocrine perturbation is possible during mouse pancreas development prior to embryonic day (E) 14, by which stage exocrine specification from multipotent progenitors is largely complete [12, 13]. However, timing is everything and several lines of evidence suggest that the critical window period for under-nutrition and the effect of GCs is later in pancreas development.

Compromised beta cell function in rat is observed following maternal dexamethasone treatment in the final week of gestation but not at earlier stages [14]. In the mouse, pancreatic GR production rises between E14.5 and E16.5, peaks at E16.5 and has fallen sharply by E17.5 [15]. Following GR inactivation, mouse pancreas appeared normal at E15.5 during major endocrine commitment due to transient Ngn3 production [16, 17]. Taken together, these data imply that GC restriction of beta cell development occurs perhaps coincident with, but more likely after, Ngn3 production and prior to that of insulin. This interpretation of a relatively late effect of GCs on endocrine differentiation would also dictate that the exocrine observations are either secondary or in parallel rather than part of an endocrineexocrine phenotypic switch mechanism.

It seems feasible that the major role of GR signalling is to restrain cell proliferation at later stages of beta cell differentiation. Following $P d x 1$-regulated GR inactivation the authors in this issue report increased BrdU incorporation as a marker of recent proliferation in insulin-positive cells as well as in nearby insulin-negative cells (Fig. 6d in [6]). Further immunohistochemistry would be useful to identify these insulin-negative BrdU-positive cells by colocalisation with transcription factors produced after Ngn3, such as neurogenic differentiation 1 (Neuro1), paired box gene 6 (Pax6), ISL1 transcription factor, LIM/homeodomain (Is11), NK2 transcription factor related, locus 2 (Drosophila, Nkx2.2), NK6 homeobox 1 (Nkx6.1) and vmaf musculoaponeurotic fibrosarcoma oncogene family, protein A (avian) (MafA), as well as other endocrine hormone markers. Potential involvement of the MODY 1 gene, $H N F 4 \alpha$ is intriguing. Dexamethasone causes a switch in use from the P2 to the P1 promoter of $H n f 4 \alpha$ and increases transcript levels in the liver [18]. Both promoters are active in the human fetal pancreas making $H N F 4 \alpha$ expression potentially sensitive to GCs during beta cell development [19]. Inactivating mutations in $H N F 4 a$ that later give rise to diabetes paradoxically present with hyperinsulinaemia and macrosomia at birth [20]; cellular levels of other genes in the insulin secretion pathway are unchanged, implying that loss of HNF $4 \alpha$ increases the number of fetal beta cells. Piecing these datasets together, GCs could act during beta cell development to increase functional $\mathrm{HNF} 4 \alpha$ which, despite being required in postnatal beta cells, seems unexpectedly to restrain fetal beta cell mass. Accurately identifying the genetic targets of GR action will be complex: the function of the nuclear hormone receptor varies widely according to the setting and includes both activation and repression [21]; as well as directly regulating transcription, GR binding to DNA can profoundly modify chromatin structure, affecting potential access to adjacent DNA for a range of other transcription factors; it can influence transcriptional activity of other factors via protein-protein interaction off DNA [21]; and genetic targets vary according to whether GC delivery is pulsatile or continuous [22, 23].

For relevance in diabetes it will be important to translate these findings from rodent models. In considering potential programming of human fetuses by GCs, a lot of attention has focussed on placental transfer of maternal cortisol during the third trimester of gestation and the adequacy or otherwise of the placental enzyme type $211 \beta$-hydroxysteroid dehydrogenase (HSD11B2), which inactivates cortisol to cortisone $[14,24]$. Although late gestation is the period that most 
profoundly influences birthweight, this phase and maternal transfer may not be the most important factors for GC programming of beta cell mass. Timed with the first wave of beta cell differentiation and islet formation [25, 26], the presence of NGN3 protein has been most consistently reported late in the first trimester and early in the second trimester of human gestation [27-29]. Reports of the transcription factor later in pregnancy are conflicting, with some groups unable to detect it [30]. During this period of 8-14 weeks post-conception, transfer of maternal cortisol across the placenta seems of secondary importance to fetal adrenocortical production; female fetuses with congenital adrenal hyperplasia due to 21-hydroxylase deficiency would otherwise not be so profoundly cortisol-deficient as to virilise $[31,32]$. In contrast, the first trimester human fetal adrenal is remarkable for its cortisol secretion, with GC action via GR in the anterior pituitary able to regulate $\mathrm{ACTH}$ secretion [33]. This raises the possibility that factors even subtly varying human fetal cortisol production, such as polymorphic variations in key enzymes, may influence pancreatic beta cell development. Concordant with these combined speculations, data from people born during or soon after the Dutch winter famine of 1944-1945 have demonstrated that impaired glucose tolerance in later life with seemingly deficient insulin secretion correlated most strongly with food restriction during their early and midgestation, but not the last trimester [34].

In summary, there has been clear progress in resolving the mechanistic complexity of gestational under-nutrition on beta cell development down to a role for a single hormone, now robustly corroborated by genetic inactivation of its nuclear hormone receptor [6]. Alongside the value of understanding such risk factors for type 2 diabetes, discovering hormones and other secreted factors that regulate beta cell development may offer clues for new drug development to enhance beta cell mass. In the case of GR, novel ligands are an area of intense pharmaceutical activity $[35,36]$. Further mechanistic understanding of GR action may even throw up new pathways for potential manipulation. However, regardless of such possibilities, as molecular research has tended to focus us ever deeper into the nucleus, it is perhaps comforting - as diabetologists and endocrinologists - that 'old-fashioned' hormone communication between our favourite organs remains important during gestation as well as postnatally.

Acknowledgements The authors receive support from the Manchester National Institute for Health Research Biomedical Research Centre. L. C. Matthews is a University of Manchester Stepping Stones Fellow. N. A. Hanley is a Wellcome Trust Senior Fellow in Clinical Science in addition to receiving funding from the Biotechnology and Biological Sciences Research Council, the Engineering and Physical Sciences Research Council, and Stem Cells for Safer Medicine.
Duality of interest The authors declare that there is no duality of interest associated with this manuscript.

Open Access This article is distributed under the terms of the Creative Commons Attribution Noncommercial License which permits any noncommercial use, distribution, and reproduction in any medium, provided the original author(s) and source are credited.

\section{References}

1. Hales CN, Barker DJ (1992) Type 2 (non-insulin-dependent) diabetes mellitus: the thrifty phenotype hypothesis. Diabetologia 35:595-601

2. Barker DJ, Gluckman PD, Godfrey KM, Harding JE, Owens JA, Robinson JS (1993) Fetal nutrition and cardiovascular disease in adult life. Lancet 341:938-941

3. Bréant B, Gesina E, Blondeau B (2006) Nutrition, glucocorticoids and pancreas development. Horm Res 65(Suppl 3):98-104

4. Puri S, Hebrok M (2010) Cellular plasticity within the pancreaslessons learned from development. Dev Cell 18:342-356

5. Zaret KS, Grompe M (2008) Generation and regeneration of cells of the liver and pancreas. Science 322:1490-1494

6. Valtat B, Dupuis C, Zenaty D, Sing-Estivalet A, Tronche F, Bréant B, Blondeau B (2010) Genetic evidence of the programming of beta cell mass and function by glucocorticoids in mice. Diabetologia. doi:10.1007/s00125-010-1898-2

7. Blondeau B, Lesage J, Czernichow P, Dupouy JP, Bréant B (2001) Glucocorticoids impair fetal beta-cell development in rats. Am J Physiol Endocrinol Metab 281:E592-599

8. Gesina E, Tronche F, Herrera P et al (2004) Dissecting the role of glucocorticoids on pancreas development. Diabetes 53:2322-2329

9. Gu G, Dubauskaite J, Melton DA (2002) Direct evidence for the pancreatic lineage: NGN3+ cells are islet progenitors and are distinct from duct progenitors. Development 129:2447-2457

10. Herrera PL (2000) Adult insulin- and glucagon-producing cells differentiate from two independent cell lineages. Development 127:2317-2322

11. Shen CN, Slack JM, Tosh D (2000) Molecular basis of transdifferentiation of pancreas to liver. Nat Cell Biol 2:879-887

12. Schaffer AE, Freude KK, Nelson SB, Sander M (2010) Nkx6 transcription factors and Ptfla function as antagonistic lineage determinants in multipotent pancreatic progenitors. Dev Cell 18:1022-1029

13. Solar M, Cardalda C, Houbracken I et al (2009) Pancreatic exocrine duct cells give rise to insulin-producing beta cells during embryogenesis but not after birth. Dev Cell 17:849-860

14. Seckl JR (2004) Prenatal glucocorticoids and long-term programming. Eur J Endocrinol 151(Suppl 3):U49-U62

15. Speirs HJ, Seck1 JR, Brown RW (2004) Ontogeny of glucocorticoid receptor and 11beta-hydroxysteroid dehydrogenase type-1 gene expression identifies potential critical periods of glucocorticoid susceptibility during development. J Endocrinol 181:105-116

16. Schwitzgebel VM, Scheel DW, Conners JR et al (2000) Expression of neurogenin3 reveals an islet cell precursor population in the pancreas. Development 127:3533-3542

17. Gesina E, Blondeau B, Milet A et al (2006) Glucocorticoid signalling affects pancreatic development through both direct and indirect effects. Diabetologia 49:2939-2947

18. Nyirenda MJ, Dean S, Lyons V, Chapman KE, Seckl JR (2006) Prenatal programming of hepatocyte nuclear factor 4alpha in the 
rat: a key mechanism in the 'foetal origins of hyperglycaemia'? Diabetologia 49:1412-1420

19. Harries LW, Locke JM, Shields B et al (2008) The diabetic phenotype in HNF4A mutation carriers is moderated by the expression of HNF4A isoforms from the P1 promoter during fetal development. Diabetes 57:1745-1752

20. Pearson ER, Boj SF, Steele AM et al (2007) Macrosomia and hyperinsulinaemic hypoglycaemia in patients with heterozygous mutations in the HNF4A gene. PLoS Med 4:e118

21. Revollo JR, Cidlowski JA (2009) Mechanisms generating diversity in glucocorticoid receptor signaling. Ann NY Acad Sci 1179:167-178

22. Desvergne B, Heligon C (2009) Steroid hormone pulsing drives cyclic gene expression. Nat Cell Biol 11:1051-1053

23. Stavreva DA, Wiench M, John S et al (2009) Ultradian hormone stimulation induces glucocorticoid receptor-mediated pulses of gene transcription. Nat Cell Biol 11:1093-1102

24. Seckl JR, Holmes MC (2007) Mechanisms of disease: glucocorticoids, their placental metabolism and fetal 'programming' of adult pathophysiology. Nat Clin Pract 3:479-488

25. Piper K, Brickwood S, Turnpenny LW et al (2004) Beta cell differentiation during early human pancreas development. J Endocrinol 181:11-23

26. Polak M, Bouchareb-Banaei L, Scharfmann R, Czernichow P (2000) Early pattern of differentiation in the human pancreas. Diabetes 49:225-232

27. Sugiyama T, Rodriguez RT, McLean GW, Kim SK (2007) Conserved markers of fetal pancreatic epithelium permit prospective isolation of islet progenitor cells by FACS. Proc Natl Acad Sci USA 104:175-180
28. Lyttle BM, Li J, Krishnamurthy M et al (2008) Transcription factor expression in the developing human fetal endocrine pancreas. Diabetologia 51:1169-1180

29. Piper Hanley K, Hearn T, Berry A et al (2010) In vitro expression of NGN3 identifies RAB3B as the predominant Ras-associated GTP-binding protein 3 family member in human islets. J Endocrinol 207:151-161

30. Yebra M, Montgomery AM, Diaferia GR et al (2003) Recognition of the neural chemoattractant Netrin-1 by integrins alpha6beta4 and alpha3betal regulates epithelial cell adhesion and migration. Dev Cell 5:695-707

31. Hanley NA, Arlt W (2006) The human fetal adrenal cortex and the window of sexual differentiation. Trends Endocrinol Metab 17:391-397

32. Krone N, Hanley NA, Arlt W (2007) Age-specific changes in sex steroid biosynthesis and sex development. Best Pract Res Clin Endocrinol Metab 21:393-401

33. Goto M, Piper Hanley K, Marcos J et al (2006) In humans, early cortisol biosynthesis provides a mechanism to safeguard female sexual development. J Clin Investig 116:953-960

34. de Rooij SR, Painter RC, Phillips DI et al (2006) Impaired insulin secretion after prenatal exposure to the Dutch famine. Diab Care 29:1897-1901

35. van Raalte DH, Ouwens DM, Diamant M (2009) Novel insights into glucocorticoid-mediated diabetogenic effects: towards expansion of therapeutic options? Eur J Clin Invest 39:81-93

36. Schacke H, Berger M, Rehwinkel H, Asadullah K (2007) Selective glucocorticoid receptor agonists (SEGRAs): novel ligands with an improved therapeutic index. Mol Cell Endocrinol 275:109-117 